conflictual subject and object statuses, and what paths there may - or may not be towards relations of greater reciprocity, are open questions. Deutscher argues that - although there are passages that point in other directions - in the 1940s, Beauvoir misguidedly treated the alterities of race and gender as distinct, largely occluding the specificities of black women's alterity in America Day by Day. It is only later, in The Coming of Age, that Beauvoir developed resources resources that Deutscher suggests could now be productively used to rework the earlier analyses of race and gender - that enable one to grasp the self as a multiplicity of often conflictual and unstable characteristics.

The last part of Deutscher's book, with its primary focus on The Coming of Age, is perhaps the richest. Here, Deutscher draws out a new conception of reciprocity that lies less in acknowledging the freedom we share with others than in our shared vulnerability. It is not only that old age comes to (almost) all of us. For the phenomenon of aging invites us more broadly to reconceptualize the subject and to consider other possible forms of reciprocity. We are all aging continuously and 'since age inhabits every subject' it invites us to focus on what we share in terms of 'exposure, vulnerability, fragility, transformation, embodied time' (p. 179). Herein lies not only an ethics but also a politics and a political economy. For, to ground reciprocity in the recognition of our shared vulnerability, we must cease to value individuals for their 'productivity,' or for their freedom or their autonomy. As its minimum precondition, as Beauvoir insists, this new kind of reciprocity will require a radical reconstruction of social and economic institutions.

\title{
Deliberative freedom: Deliberative democracy as critical theory
}

\author{
Christian F. Rostbøll \\ State University of New York Press, Albany, NY, 2008, 312 pp., hardcover, \\ \$80.00, ISBN 13: 978-0791474594
}

Contemporary Political Theory (2010) 9, 258-261. doi:10.1057/cpt.2009.24

Christian F. Rostbøll's book Deliberative Freedom: Deliberative Democracy as Critical Theory is unique for several reasons. First, it is the first book that deals

258 (C) 2010 Macmillan Publishers Ltd. 1470-8914 Contemporary Political Theory Vol. 9, 2, 251-261 
fully with the complex relationships between multiple dimensions of freedom and democracy. Second, Rostbøll provides a new deliberative democracy description that is different from the political liberalism of Rawls and the critical theory of Habermas. Third, this book tries to build a new theory of freedom and democracy that aims to elucidate the different dimensions of freedom that deliberative democracy embraces.

Political Science professor Christian F. Rostbøll of the University of Copenhagen begins with the questions that have not been addressed in the literature of deliberative democracy, such as 'What is it about democracy that makes citizens free?' 'Which conception of freedom does democracy promote?' 'Which model of democracy makes citizens most free?' Rostbøll has an eagle eye for the right questions. From Pettit's republicanism to Elster and Sunstein's theories on endogenous preference formation, this book surveys, criticizes and goes beyond the broad literature on democracy and freedom.

Rostbøll builds his argument by differentiating deliberative democracy from the tradition of self-interest liberalism and republican freedoms. In Chapter 1, he argues that although negative freedom models of democracy have various problems, the mechanisms of aggregation and the idea of negative freedom play a role in deliberative democracy. According to traditional deliberative democrats, aggregative democracy and negative freedom aim to protect private interests and preferences. He criticizes the deliberative democrats because of their rejection of what comes out of the negative freedom and aggregative freedom. He continues the same criticism in Chapter 2, in which he presents Philip Pettit's notion of 'freedom as non-domination' as a specific example of republican freedom and shows its relation to deliberative democracy. Similar to Chapter 1, in Chapter 2 Rostbøll criticizes not only the presented theory of freedom - republican conception of freedom - but also the deliberative democracy literature. His main criticism of both liberal and republican traditions is that they lack the important dimension of freedom, which is 'internal autonomy'.

In Chapter 3, Rostbøll presents the vital notion of deliberative democracy, the issue of autonomous preference formation. His main argument is that both Elster and Sunstein's theories on endogenous preference formation do not incorporate all dimensions of freedom. Rostbøll appraises these two theories from the lenses of critical theory. The most important insight is that deliberative democracy is different than a paternalist democracy that assumes that people do not know what is good for themselves. Deliberative democracy, therefore, rejects the notion of paternalism and instead supports extensive public deliberation as a means of dealing with non-autonomous preferences. Rostbøll continues his search for a theory of deliberative freedom by explaining Rawlsian and Habermasian conceptions of deliberative democracy in Chapters 4 and 5. Rawls' view of freedom, which is beholden to liberal 
tradition of toleration and accommodation, is accepted as unfortunate and uncritical. Although Rostbøll and Habermas share the same commitments, Rostbøll's theory differs from Habermas' 'by being based on a theory of freedom rather than on a theory of argumentation' (p. 135). On the one hand, Rawlsian deliberative democracy focuses only on negative freedom and overlooks the importance of emancipation. On the other hand, Habermasian deliberative democracy sees internal autonomy as part of public autonomy.

Rostbøll attempts to explain the negative dimension of freedom in Chapter 6. In this chapter, the characteristics of deliberative freedom come into sharper focus. Rostbøll argues that procedural independence 'takes it seriously that even to enjoy opportunities not only for acting freely but also for forming preferences freely some positive state action may be necessary, and that without such encouragement and facilitation of the creation of a democratic ethos, negative freedom will not necessarily reinforce democracy or the full exercise of deliberative freedom' (p. 173). He continues this claim in Chapter 7. Although it would violate freedom to legally enforce participation, law could be used to 'encourage' public deliberation participation. However, Rostbøll's most important nuance in the obligation of participation is that it must be moral. He claims that the key principle of the deliberative democratic view of freedom is mutual interdependence, and that it is required in gaining the necessary insights - knowledge about the interest, needs, and opinions of others and ourselves, knowledge about what can be justified to others and what we want together, and knowledge about causal relationships (pp. 183-184) to live in freedom (p. 207). In short, deliberative freedom, procedural epistemic conception of freedom, is concerned with each individual's ability to judge political decisions.

Deliberative Freedom: Deliberative Democracy as Critical Theory is an ambitious book that provides a comprehensive explanation of what deliberative democracy should look like, and how the multiple dimensions of freedom should be included in deliberative democracy. Yet, the main limitation of this work is that it does not explain how deliberative freedom works in practice. Although the author briefly mentions some organized forms of deliberation, namely 21st Century Town Meetings and Citizens Juries, the reader is left needing to know how these public deliberations will gain legislative influence. Another limitation of this book is that it does not really examine what happens if citizens do not want to be involved in public deliberation. Rostbøll argues that "moral obligations do not depend on whether we like to fulfil them or not' (p. 207). Yet this does not explain what happens if people are happy with the lack of deliberative processes. In any event, Rostbøll successfully explains why there is a need for a theory of deliberative freedom and the major shortcomings of deliberative democracy literature. 
I believe this book represents a strong beginning to understanding deliberative democracy from a different perspective. Although the focus of Deliberative Freedom: Deliberative Democracy as Critical Theory is to demonstrate the importance of all citizens having the chance to participate in public deliberation, I still left needing to know more about how this process of public deliberation becomes a fundamental element of democracy in modern societies. Anyone looking for a well-argued view of what the need for deliberative democracy is will find this book well worth reading. Still, it is worth noting that Rostbøll's often intense theoretical discussions make this book useful only for graduate seminars.

Aysegul Keskin

Kent State University

Kent, OH, U.S.A 